\title{
19 Pentecostal Charismatic Christianity and the management of precarity in postcolonial Zimbabwe
}

Josiah Taru

\section{Introduction and background}

This chapter starts with a commentary on the conceptualisations of, and common narratives produced by, researchers that explore the intersection between Pentecostalism, modernity and development in Africa. The rest of the chapter focuses on the political and economic crisis in postcolonial Zimbabwe and ways in which One Ministry of God (OMG) is assisting its members to respond to the crisis. Finally, some conclusions are derived from the discussions and examples raised in the chapter. The main argument furthered in this chapter is that some variants of Pentecostal Charismatic Christianity have oriented their activities in a way that cushions their members from the vagaries of the multi-layered Zimbabwean political and economic crises.

Several studies have portrayed Pentecostal movements as responding to objective realities of neo-liberal capitalism (Comaroff and Comaroff 2001), modernity (Meyer 1998a; Comaroff and Comaroff 1997) and political and economic crises (Gifford 2002, 2009, 1994) through spiritual means. Pentecostalism is portrayed as a vehicle of spiritualising and enchanting situations and problems that characterise some African postcolonial states. Drawing from ethnographic data gathered from One Ministry of God $(\mathrm{OMG})^{1}$ in Zimbabwe, this chapter shows that OMG has instituted pragmatic strategies to deal with state-induced precarity and vulnerability. There are efforts being made to improve the lives of members in the 'here and now' through pragmatic ways.

The data presented in this chapter was gathered through ethnographic fieldwork spanning from June 2016 to August 2018. Most of the data was gathered through in-depth interviews conducted with $55 \mathrm{OMG}$ members, and from field observations. Furthermore, the researcher stayed with a family that was part of the OMG. This facilitated observations of everyday lives of Pentecostal Charismatics, especially ways in which the teachings at $\mathrm{OMG}$ are incorporated in guide decision-making. The researcher attended and took part in most of the church services and events organised by OMG. Lastly, some of the data presented in this chapter was acquired from sermons, OMG literature, newspaper articles, DVDs and CDs. 


\section{Religion, modernity and development}

The emphasis on science as the only way of understanding our world during the enlightenment project portrayed religion as militating against progress. Oftentimes religion is relegated to the realm of the metaphysical which has little bearing on the realities of the members within religious communities. Most conceptualisations of religion emphasise the irrational, mysticism and supernatural nature of religion (Asad 1993, 27-54; Coleman 2011; Marshall-Fratani 2014). Modernisation theorists portray religion as an atavistic form of knowledge with little significance in issues of progress and development. Concomitantly, religion is overlooked in most developmental processes. Modernisation theorists construct development as planned, rational and future oriented and religion as the opposite. The differences in the conceptualisations of religion and development gives a false sense of incompatibilities between the two realms. As Scott (1998) and Ferguson $(1999,2006)$ have shown, modernity and development projects have produced unintended consequences undermining the rational and planned aspects that are over-emphasised by modernisation perspective and western discourse on development.

Weber (1930) argues that Calvinism was the handmaid in the development of capitalism in Europe. Calvinism encouraged values of saving, hardworking, asceticism and thriftiness among its members (Lessnoff 1994). These values guaranteed material prosperity which was considered as a visible sign for salvation (Samuelsson 1957). Weber avers that Calvinists' Protestant ethics were instrumental in the development of capitalism as an economic system. Scholars continue to search for the role of religion in developing ethos that have a bearing on social and economic development. Studies conducted in Southern Africa are starting to acknowledge the role of religion, especially Pentecostalism as conduit for social and economic development (Freeman 2015). Lawrence Schlemmer's (2008) and Peter Berger's (2008) research papers, titled Dormant Capital and Under the Radar respectively, bring to the fore the potential social and economic significance of Pentecostalism in South Africa. Pentecostal movements are engaging in a number of projects that have a bearing in the development of surrounding communities. Furthermore, Pentecostal Charismatic Christianity engages in several charity activities that enable marginalised members of society to lead decent lives (Miller and Yamamori 2007).

\section{Theological and missiological orientations of PCC}

The term Pentecostal Charismatic Christianity has been used to distinguish contemporary PCCs from the first wave Pentecostal movements that emphasised holiness. The emergent variant of Pentecostalism has been identified as the Third Wave of Pentecostal movements, Neo-Pentecostalism and new churches (Gifford 2004, vii). I follow Robbins' $(2004,117)$ and Meyer's (2007) usage of the term Pentecostal Charismatic Christianity to refer to Pentecostal movements whose teachings involve elements of prosperity gospel, entrepreneurship 
and are accommodative of material and financial success. Pentecostal Charismatic movements have shifted their discourse from the premillennialism widely found among classical Pentecostalism. ${ }^{2}$ Classical Pentecostal theology is premillennial in nature, stating that Jesus Christ will establish and reign over an earthly kingdom for a millennium. ${ }^{3}$ The established earthly kingdom will replace the one we are part of (Wacker 2001). Premillennial theology encourages retreatism in early Pentecostals (Wacker 2001). The bulk of classical Pentecostal movements concerned themselves with directing believers towards issues that will guarantee them life after death spiritual issues (Wacker 2001, 217-219; Christerson and Flory 2017, 92).

PCC have adopted postmillennial theology in which religious movements are concerned with and involved in 'creating a heaven on earth' (Christerson and Flory 2017, 92). Postmillennial theology promotes a 'dominionist' stance in believers, by encouraging believers to take-over the world and re-fashion the world in a way that pleases God (Christerson and Flory 2017). PCC are involved in world-making (Marshall 2009; Robbins 2004, 130) with the imageries preached informing the actions that the Pentecostal Charismatics engage in to create the world projected in the teachings and imageries (Meyer 2010, 118). PCC are interested in the 'here and now', positioning religious movements in a space in which they must deal with some of the effects of the poorly performing Zimbabwean state-systems.

\section{One Ministry of God: theological and missiological orientations}

The Zimbabwean religious landscape has experienced an increase in the number of PCCs over the past two decades (Chitando 2009; Taru and Settler 2015). PCC have increased in both numbers and public visibility. OMG is one such PCC which is visible on Zimbabwean religious landscape.

OMG is a religious movement that has managed to tremendously grow in terms of membership and branches. OMG membership is drawn from the crosssection of the Zimbabwean society. Business executives, politicians, small business owners, informal traders, the unemployed and vendors constitute the bulk of OMG members. Founded by Prophet $\mathrm{Ben}^{4}$ as a lunch-hour interdenominational prayer session, $\mathrm{OMG}$ has rapidly grown into a transnational movement. OMG's website claims that over 70,000 people attend its services per week (OMG website, accessed in June 2017). The mission of OMG is spelt out as 'to Build A God Society for All People and All Nations and Reaching Out'. OMG members view themselves as the chosen people tasked with creating a society on behalf of God. OMG members believe that the 'God society' will be built in the 'here and now'. On its website OMG claims that it seeks to 'enact a revolution' by equipping members with skills, knowledge and information 'relevant to every 21 st Century Believer'. The mission to build the 'God society' will not be achieved spiritually but physically through the efforts by both OMG and its members. The drive towards constructing a 'God society' is guided by the need 
to create conducive societies 'in which people can flourish and live life abundantly's (Fieldnotes 7 January 2017).

Prosperity gospel comes in many strands, often retooled to suit the local cultural, political and economic context within which the gospel is preached (Haynes 2012). From the sermons preached by Prophet Ben, prosperity includes spiritual, physical and material well-being that enhances the standard of living for congregants. During a service Prophet Ben told congregants that they 'were not created to live in any form of deprivation' (Prophet Ben, sermon, 26 August 2017). Similar proclamations from the pulpit are common. In 2016 Prophet Ben informed the congregants that God gave OMG members dominion over the earth so that the congregants can flourish unfettered by anything (Prophet Ben, sermon, 24 July 2016). Furthermore, OMG's devotional booklet contained similar teachings that encourage $\mathrm{OMG}$ members to dominate in some aspects of their lives. In the same devotional booklets, the prophet wrote that 'He (God) never wanted you to suffer ...' (OMG Devotional booklet, 12 June 2017). These teachings explicitly reveal that God aims to richly reward OMG Pentecostals in whatever form they want it, be it health, family, business success, employment, houses and vehicles. The teachings shape ways in which OMG members construct their personhood and how they understand their position in the world. This dominionist theology must be understood within the Zimbabwean context.

\section{Precarity and uncertainties in postcolonial Zimbabwe}

Anthropologists distinguish between precariousness and precarity to capture the everyday experiences of people living in conditions of insecurities and vulnerability (see Butler 2004). Humanity exists in condition of precariousness because of unavoidable vulnerability and insecurities that come as a result of our shared existence. Precariousness is part of our collective lives. The concept of precarity points to 'specific way that socio-economic and political institutions ... distribute the conditions of life inequality' differently to people (Millar 2017, 4). The source of precarity is mismanagement of and by institutions that have a direct bearing on the lives of people. Precarity is characterised by a 'life without the promise of stability' (Tsing 2015, 2). In the case of Zimbabwe, precarity is a result of ill-governance by the postcolonial government, whose policies have heightened vulnerability, insecurities, hopelessness, anxiety and despair among Zimbabweans (Rotberg 2002, 94; Jones 2010).

From the 1990s multi-layered political and economic crises have dogged the postcolonial Zimbabwean state. The adoption of the neo-liberal Economic Structural Adjustment Programme (ESAP) in the 1990s increased vulnerability and insecurity among the bulk of Zimbabweans. Poverty levels rose to such high levels that in the United Nations Human Development Report of 2010 Zimbabwe ranked at the bottom. For the past two decades, the economic situation in Zimbabwe has been worsening, with the GDP halving in a decade (Majengwa, Kasirye and Matema 2012). Inflation rates jumped from 49 per cent 
in 2000 to 231,000,000 per cent in 2008 (Gono 2008a; 2008b). High inflation rate reduced disposable income and eroded savings. The local currency lost its value and was demonetised. The introduction of the multi-currency in 2009 introduced a degree of stability in the economy. The United States Dollar (US\$) was the preferred currency with prices pegged in United States Dollars and banks dispensing United States Dollars (Kanyenze, Chitambara, and Tyson 2017, 7). However, by 2015 United States Dollars were in short supply and the government introduced bond notes. ${ }^{6}$ As of 2014 the informal employment rate had escalated to over 94 per cent (Kanyenze, Chitambara and Tyson 2017, 1). The worsening economic conditions led to the informalisation of the economy, pushing the bulk of Zimbabweans into the informal economy (Jones 2010). The state exacerbated the situation by unleashing the police and the military to destroy informal marketplaces and get rid of the informal economy through 'clean-up' operations (Tibaijuka 2005).

In 2005 the government embarked on Operation Murambatsvina ${ }^{7}$ which destroyed houses and informal markets that the majority of urbanites depend on. 92,460 houses were demolished leaving more than 134,000 people homeless (Tibaijuka 2005). During Operation Murambatsvina, the government also destroyed means of livelihoods for most urbanites by destroying informal marketplaces. The operations left most Zimbabweans without home or source of livelihood. Urbanites were displaced into rural areas. The palliative Operation Garikayi/Hlalani Kuhle $e^{8}$ provided fewer houses than those demolished during Operation Murambatsvina. Below I will discuss ways in which OMG has organised its members into a housing cooperative aimed at assisting OMG members to secure places of residence.

State institutions are responsible for the suffering of most Zimbabweans. As the state fails in creating a conducive environment for Zimbabweans to lead decent lives, most Zimbabweans are turning to self-help projects. Religious movements, housing cooperatives, burial societies and rotating credit schemes have increased in the last two decades. In the face of inadequacies of the state welfare system and policies, citizens are shifting their attention away from the state and are looking towards alternative institutions for assistance in improving livelihood and well-being.

\section{Pentecostal personhood and well-being}

The act of converting to $O M G$ and being baptised is read as the first victory one scores against witchcraft, poverty and sinful life (cf. Maxwell 1998 on converts who joined Zimbabwe Assembly Of God Africa, ZAOGA). New converts are reminded that their choice to follow Jesus is not easy, there are opposing ancestral and satanic forces that have to be overcome. From the onset, converts are portrayed as victors in the spiritual warfare against witchcraft and demonic forces. Baptism is one ritual that physically conveys the symbolic changes in the personhood of the converts. For OMG members, the act of being immersed in water and re-emerging signals death of the old self and the emergence of the 
new self, empowered by the Holy Spirit. These transformations are evident in the narratives of some of the congregants. One OMG member narrated that:

when I converted in 2012, I was following my friends who were already members of OMG.... It was only after being baptised that I thought carefully about being a Christian. We were taught what baptism mean for Christians ... it was a way of reconnecting to our source - God. Once we are in good books with the source, what will I lack? The teachings helped me to leave my old habits. I learnt that God loves us and that we are of importance to Him. We are closer to His image than angels, we are more important to God and we must never look down upon ourselves.

(interview, 2 September 2016)

Baptism is a ritual that facilitates OMG members 'break with the past' (see Meyer 1998b). As pointed out in the above excerpt, conversion is a process of rejuvenation and anchoring one's life. God becomes the anchor in converts' lives. The new relationship with God is instrumental in shaping OMG's members perception of themselves. OMG Pentecostal Charismatics conceive themselves as victors who have a direct link to the source of life - God. The construction of selfhood around ideas of victory is furthered in Eucharist rituals in which members embody the blood and body of Jesus. Among OMG members the blood of Jesus is considered so powerful that it can heal any form of sickness, defeat demons and witchcraft that works against members' prosperity. These rituals endow OMG members with confidence and optimism on most issues that they participate in. Apart from rituals, the message in most OMG songs is optimistic (Gukurume 2017).

Apart from cultivating personal relationships with God, OMG members develop relationships among themselves. OMG provides fertile ground for the emergence of social networks of support and opportunities among members. Members are organised into section and zonal groups. These groupings allow for the development of intimate relationships among members because the groups are small and based on residential locations. Social relations based on religious affiliation form social and economic capital that individuals depend on in improving their lives. A member of OMG who owned a hardware store relied on purchases by builders and plumbers who are members of OMG. The builders always brought their clients to this hardware store. The preference to buy from a fellow Pentecostal Charismatic attests to the intimate bonds developed by members. OMG-based social networks provided by the groupings are also important for members in the informal economy. The social networks double as business networks, as clients and suppliers are derived from the members of the small groupings. OMG members prefer obtaining services and products from fellow church members. OMG members from different social and economic classes form social relationships through sectional and zonal groupings that meet during mid-week gatherings. Social networks provide support, love and care that cushion members from the vagaries of the economic crisis (Clarke 1994, 
216-217). The groupings focus on addressing spiritual, social, economic and health issues that affect members.

\section{New subjectivities: rationalisation and methodical lives}

Weber (1930) argues that Calvinism brought with it a rationalising and systematic approach to life. This allowed for the emergence of ethics that laid the foundation for capitalism. The practices Weber describes are being reproduced by OMG Pentecostal Charismatics. OMG instils methodical approaches to congregants' lives through various strategies. As I have alluded to above, baptism represents a break with one's past. The break is both spiritual and physical. Pentecostal movements' close-knit religious communities are instrumental in changing the lifestyle of members. David Maxwell (2006) notes male members of ZAOGA transformed from profligate lifestyle of alcohol consumption, extra marital liaisons and funding traditional rituals to supporting relatives. Pentecostalism, in the case of ZAOGA, encouraged frugal lifestyles supported by the meagre income members earned. Furthermore, the reduction in alcohol consumption and support given to relatives and sexual partners translated into increased attention given to the immediate family. The focus on the immediate family produced family structures that are often associated with the middleclasses. In the case of ZAOGA. Pentecostalism promotes stable families whose members focus on improving their lives. OMG is reproducing similar values and practices. OMG discourages extra-marital affairs, smoking and drinking among its members. In one of the church services I attended in 2016 Prophet Ben exposed a member who engaged in an extra marital affair (fieldnotes, June 2016). ${ }^{9}$ Publicly exposing unfaithful members during service acts as a social control mechanism to discourage other members. OMG organises family days and events for couples to strengthen the family unit. The focus on the immediate family and distant relatives reduces expenditures on activities that do not directly benefit the family.

OMG has inculcated members with methodical approaches on issues concerning money and time management. For OMG Pentecostals time dedicated to anything can translate to money. OMG members either contribute money or time to OGM. These two types of donations are treated in the same manner. Due to this most members manage their time diligently because they know its value. Also, a number of respondents referred to what they called 'The Kingdom Prosperity model' that guides members on issues of money, investment and savings. The model brings rationalisation when it comes to financial matters. For every dollar earned, 10 per cent is set aside for tithe (interview, 29 September 2016). Apart from the 10 per cent reserved for tithe, 20 per cent is earmarked for business projects that the congregants have interest in. Some congregants fund cross-border trading, vending and fast-food businesses from the 20 per cent. The remaining 70 per cent is for congregants' free-will offerings ${ }^{10}$ and consumption. The model instils systematic expenditure and planned use of money. The model promotes the culture of saving with the aim of starting income generating projects. Furthermore, 
the model encourages $\mathrm{OMG}$ members to be entrepreneurial as a certain amount of income is reserved for and dedicated to income generating projects. The model applies to all congregants regardless of their variations in income levels. Those that earn less will save less and are thus more likely to engage in small businesses such as vending. While the model exists, there are some congregants who failed to put the model into practice due to erratic and meagre incomes. Despite the failure to follow the model, several congregants expressed their willingness to follow the model once stability returns into their lives.

Deborah James $(2015,2012)$ found that in South Africa, Pentecostalism has moulded black South Africans into the habit of saving through teachings that equip them with financial management skills. Some of the Pentecostal Charismatic Christianity in Sub-Saharan Africa are promoting rationalisation and methodical lifestyles that positively impact the livelihood of members and their families. The methodical lifestyles are mechanisms through which families adjust to the economic realities obtained in Zimbabwe and the meagre disposal income that most households and families survive on. The Kingdom Prosperity model optimises income by earmarking and compartmentalising the income into categories that the members have to satisfy. There is long-term standardisation of expenditure on things that are considered important by congregants. Budgets drawn by some of the members I interviewed showed a sustained focus on funding income generating projects and on household provisions. The concomitant result of organising expenditure along the model is that it brings a methodical way of spending and saving congregants' finances.

There is a general consensus among OMG Pentecostals that money and wealth do not affect one's spirituality. From the sermons by Prophet Ben and interviews with members, OMG Pentecostals do not consider money and consumption as corrosive to spirituality. Money and wealth are creatively incorporated into OMG theology and liturgy. A male interviewee noted that

Christians must be wealthy, more wealth than heathens. Jesus was wealth, soldiers fought for his robes after his crucifixion.... Money on its own is not evil, rituals performed on the money may be evil. If money is evil, why is it that more than half of Jesus' parables are about money?

(interview, 17 June 2016)

OMG members accept money as neutral and value-free. This theological stance encourages OMG Pentecostals to actively seek money among other things. Studies among some American Protestant movements have shown that believers are forced to withdraw from wealth accumulation and conspicuous consumption as these two are thought to interfere with spiritual growth (see Sorokin 1992; Schwartz 1994; Stillman et al. 2012). Acceptance of money as a neutral medium of exchange and store of value produces an elective affinity towards amassing of wealth. OMG Pentecostals seek money and wealth openly without fear of being labelled materialistic. For OMG members, amassing money is a sign of divine blessings. 


\section{Josiah Taru}

To enhance members' possibility of flourishing, OMG partnered Old Mutual financial services ${ }^{11}$ to train members in financial literacy. Furthermore, OMG organises business conferences and workshops meant to teach congregants about financial and investment management. OMG makes deliberate efforts to invest in developing congregants' financial intelligence, especially bookkeeping and basic accounting. These workshops inculcate skills and knowledge that are essential for both households and business budgeting. As mentioned, some of the families kept records of expenditures and income. In some families the purchases of foodstuff, clothes and other items is planned and diarised. One of the booklets provided to OMG members by Old Mutual tackled issues of financial planning, financial vision and building asset base. The booklet is written in a highly accessible way to cater for congregants from different economic and educational background. Most of the lessons are presented as allegories derived from animals. ${ }^{12} \mathrm{OMG}$ is tapping into the expertise of corporates to provide training and support for its members. OMG does not rely on spiritual approaches to improve the livelihood of its members, it is partnering with corporates that understand the operations of the economy and of money.

\section{Entrepreneurship and formalisation}

Empowerment is a buzzword in Zimbabwe, with both government, civil society and churches moulding their approaches around the concept of empowerment. Despite the government's efforts towards empowering citizens, the ZANU PF-led government has failed. During the 2013 elections ZANU PF manifesto rested on three pillars namely: Indigenize, Empower and Develop. The actions and policies of the ZANU PF government are contrary to these values. The government went on to demolish the informal market and criminalise income generating activities that supported the bulk of Zimbabweans in the urban areas. OMG has taken it upon itself to empower and develop its members by supporting small business enterprises operated by members. The bulk of PCC in Zimbabwe are incubators for nurturing small businesses owned by members. Maxwell (2006) notes that ZAOGA spurred entrepreneurship through the 'talents initiative'. Pentecostals were encouraged to expand sources of income by running side-business ventures. Most of the business ventures were compatible with the formal employment. Maxwell (2006) sums that Pentecostalism promotes 'penny capitalism' whose proceeds supplement income from formal employment.

ZAOGA is one of the oldest local Pentecostal movements established in Zimbabwe and most of its members were formally employed in the civil service (Maxwell 1999). OMG came into existence when the postcolonial state experienced economic and political crisis. Chances of formal employment have drastically been reduced, leaving graduates with few options. Under such circumstances, OMG does not promote entrepreneurship as side-business ventures that only complement formal employment, but entrepreneurship is promoted as the main source of income and livelihood. Prophet Ben has encouraged his followers to be entrepreneurial and operate businesses rather 
than search for formal employment. In a sermon Prophet Ben remarked that 'waged employment is form of slavery which must be escaped' (sermon, 26 August 2016). Prophet Ben's message speaks to an obtaining situation in which most industries have collapsed.

OMG further encourages its members to formalise their business enterprises. $\mathrm{OMG}$ has facilitated the registration of unregistered companies and businesses operated by its members by subsidising the registration process. Furthermore, $\mathrm{OMG}$ engaged personnel to draft the documents required for registration. One female congregant told me that in $2015 \mathrm{OMG}$ assisted a number of congregants to register their businesses through the drafting of required documents and paying half of the cost involved (interview, 17 February 2017). While most small-scale businesses in Zimbabwe are unregistered, OMG is initiating the transformations of businesses from an unregistered status to a registered status. In a highly informalised economy, the formalisation of businesses comes with several benefits. OMG initiatives of registering businesses lower the level of precarity inherent in the informal economy. Registered businesses can apply for lucrative tenders. Furthermore, registered businesses have access to funds provided by banks and other financial institutions. In this way, OMG's initiative opens business opportunities for members' enterprises. These opportunities are lacking for most businesses that operate in the informal economy.

As highlighted above, OMG provided capital for some of its congregants to kick-start businesses. The capital was provided to congregants who attended business and financial workshops that are organised. OMG has a number of programmes meant to assist budding entrepreneurs. In August 2016 I attended events such as golf tournaments, breakfasts and lunches organised for the entrepreneurs to meet business executives and business owners. OMG is the conduit through which budding $\mathrm{OMG}$ entrepreneurs are linked to established business executives for mentoring and synergies. OMG provides a gateway through which the entrepreneurs among its members can connect to the business world. Prominent business executives graced the occasions and interacted with OMG Pentecostals.

OMG is fostering a vibrant internal economic community among its membership. While beliefs and rituals unite members into a religious community, an economic community is fostered through church-based business directory. Every year members advertise their businesses in a church-based business directory. The directory creates consumers out of congregants. The directory features businesses owned by members only. Entries into the directory are regardless of the size and type of business one runs. OMG as an organisation and its members prefer to purchase services and products from businesses owned by members. $\mathrm{OMG}$ is currently constructing its headquarters and some of the construction material were acquired from a hardware shop owned by members (interview, 12 August 2016). One of the hardware shop owners noted that OMG paid market prices for the services his company provided. OMG creates a ready market for most congregants' businesses. Congregants in fashion and designing, baking and confectionary as well as in hair styling trade readily find consumers through the 
directory and can provide services during OMG events. OMG is a network of support, opportunities and relations that assist small entrepreneurs to establish themselves in a poorly performing economy.

\section{Moral economy and housing provision}

In 2005 more than a million Zimbabweans were on a government housing waiting list (Tibaijuka 2005). While the state withdrew from social welfare provisioning, most Zimbabwean were forced into the informal settlements as they failed to afford buying houses from private developers. To worsen the situation, those in the informal economy had limited access to loans and mortgages from financial institutions such as banks that offer salary-based loans. The bulk of Zimbabweans remain excluded from accessing decent houses and accommodation. Zimbabweans have organised themselves into housing cooperatives (Chirisa, Gaza and Bandauko 2014; Paradza and Chirisa 2017). The housing cooperatives pose several challenges to members. Most home-seekers are duped of hard-earned money by housing cooperatives' management committees. Furthermore, other housing cooperatives have misled members to construct houses on undesignated land. Mistrust and suspicion between members and management committees characterise most housing cooperatives. Furthermore, the government has demolished housing structures erected on undesignated land. ${ }^{13}$

OMG has organised its members into a housing cooperative. The housing cooperative is organised in a different way to most housing cooperatives in Zimbabwe. Most housing cooperatives are composed of people who come together for the purpose of pooling together resources for the provision of houses. Members often lack prior intimate relations. Cases of housing cooperatives' management committees defrauding members are common in Zimbabwe. The housing cooperative at $\mathrm{OMG}$ is constituted by members who already have relations as they are all members of OMG. Furthermore, the moral economy of trust, honesty and piety inform the relations and interactions among members, and between the management committee and the members. The clergy has constructed itself as a caring and honest leadership interested in improving the well-being of members. Furthermore, the belief in God binds the members together. The housing cooperative is an extension of OMG, it is constructed as a moral community in which trust and care are evident. Prophet Ben is the ceremonial patron of the housing cooperative. The moral economy of trust and honesty upheld by members of the OMG housing cooperatives is absent in most housing cooperative in Zimbabwe.

OMG housing cooperative managed to pool together US $\$ 1.4$ million in fifteen months (fieldnotes, September 2017). ${ }^{14}$ Once this substantial amount was raised, the management committee consulted the membership on the way forward. From interviews I gathered, it can be shown that housing cooperative members instructed the management committee to purchase land from a private owner as a way of avoiding procuring land from local authorities and the state. The decision to purchase land from private owners is meant to cushion members 
from insecurities associated with land allocated by the local municipalities and state. ${ }^{15} \mathrm{OMG}$ learnt from a misunderstanding that occurred a few years ago when the central government blamed the local municipality for corruptly allocating OMG a place to build its headquarters. To avoid the same pitfall, members are opting to purchase land from a private owner. The housing cooperative has engaged an architecture firm to draw building plans for the houses and to design the OMG city. The housing cooperative is making frantic efforts to transform the goals of homeownership into a reality for its members.

The housing cooperative has been instrumental in helping female congregants in owning houses. One Pentecostal congregant rhetorically retorted:

Who told you that you can't own a house before marriage? Have your own house so that your future spouse will know that you are a focused partner. For wives they can own another house in their names, if funds permit.

(conversation with OMG congregant, 7 January 2017)

When I attended the Annual General Meeting for the project on 7 January 2017, female congregants who had registered for the project outnumbered males. One female congregant could not hide her joy that, after years of renting, the housing cooperative will assist her to own a house. If the project goes according to plan, the houses will be constructed by a building society that has been engaged to construct the houses. Involving the building society would reduce construction of sub-standard structures that would 'spoil the vision and image of the prophet' (conversation with OMG member, 7 January 2017). The existence in Southern Africa of legal, cultural and economic hurdles that mitigates women's access to urban houses is well documented (Goebel 2015, 29). The OMG housing initiative is an attempt to dismantle the historical system that denies low income women from owning houses in their own name.

For OMG Pentecostal Charismatics the construction of the houses goes beyond mere provision of accommodation. It is about parading the nature and type of God they believe in. Lodging and rented accommodation are considered a misrepresentation of the God worshipped by OMG members (Prophet Ben, sermon, June 2016). The establishment of the housing cooperative is a way of making a connection with the ideal society promoted by the clergy in sermons and teachings.

\section{Spiritual security and agency}

Most Pentecostal Charismatic movements' understanding of the world is informed by the belief in spiritual warfare (Maxwell 1998, 2006; Meyer 2005, 2003). OMG is not an exception, its construction of the world is informed by the same beliefs that blame the devil and his agents for most mishaps such as accidents, sickness, unemployment and infertility that some of the congregants experience. The devil is portrayed as a nemesis that works against Pentecostals 
who want to flourish. For OMG Pentecostals, the crucifixion of Jesus is the source of their desire to prosper. The death of Jesus marked a turning point in the lives of believers. Jesus took with him most of the problems that bedevilled humanity: poverty, diseases, sadness and slavery. Despite his death, the devil and its agents continue to inflict humanity with these problems (interview, 23 June 2016). Biblical scriptures are often cited to support the existence of the spiritual warfare. Most interviewees cite John 10 verse 10 which gives a comparison of the devil and Jesus to believers. ${ }^{16}$

There is a sense of 'spiritual insecurity' that characterises the lives of most OMG Pentecostals (Ashford 2005). The devil and its agents are the sources of what Ashford (2005) calls spiritual insecurity. This spiritual insecurity is illustrated in an interview excerpt below:

The devil does not tire my friend, he uses different agents to bring people down, at one time its demons, sickness and other close relatives. Some four years ago, I graduated from university, but I could not find a decent job. I applied to all NGOs that I knew had offices here (Harare) but none even sent a regret letter. Neighbours mocked the prophet because I could not get a job. I was disappointed, I was hopeless. But I remained steadfast in prayer and in my faith, I knew it was the devil's plan to shake my faith ... but I didn't. I increased the intensity of prayers and fasting, I also upped applications for employment. I finally got a job and the devil attacked me through another way, this time my mother, she fell ill. I spent lot of money on her treatment, my income was going towards her medical bills, I was broke yet I was employed.

(interview, 19 December 2016)

The challenges that OMG Pentecostals face are explained in the context of the cosmic struggle between God and the devil. The retooling of the challenges that the Pentecostals encounter and the finding of meaning in spiritual warfare inculcates perseverance in OMG Pentecostals. The fears and challenges that the interviewee expressed are fears that characterise most Zimbabweans. However, OMG Pentecostals frame the challenges in terms of spiritual warfare. Furthermore, OMG Pentecostals identified prayer and fasting as the source of spiritual security and stability. Pentecostal rituals such as fasting, prayers, baptism and Eucharist services were noted to hedge members from the economic and political instabilities prevailing in the wider society. Most OMG Pentecostals feel secure in the 'durawall' 17 of faith, network of assistance and ritual that OMG provides for members (cf. Maxwell 2006). This goes beyond spiritualising challenges and problems as described by Gifford (2004) in the case of Ghana.

\section{Conclusion: towards OMG politics of hope}

Writing on culture and by extension religion, ${ }^{18}$ Appadurai $(2013,292)$ laments that anthropologists ignore ways in which 'cultural systems, as combinations of norms, dispositions, practices and histories, frame the good life as a landscape of 
discernible ends and of practical paths to the achievement of those ends'. In our case, OMG has a model of what constitutes good life and often spells out clear strategies for achieving good life. Appadurai $(2013,295)$ conceptualises good life as 'what many people hope to achieve' in order to flourish. Models of good life preached at OMG have the capacity to aspire congregants to desire a good life. The aspirations for health, happiness, decent housing and running successful businesses are not individualistic among OMG members; it is collective and shared. Furthermore, it lays the foundation upon which congregants think about the future. Good life is achieved through ethics of possibilities that give hope for people to continue forging towards improving their lives. Ethics of possibilities is a navigational capacity consisting of 'ways of thinking, feeling and acting that increase the horizon of hope, that expand the field of the imagination ... and widen the field of informed, creative and critical citizenship' (Appadurai 2013, 215). OMG achieves this through sermons, teachings and testimonies that keep the hope and aspirations of member alive. Furthermore, the teachings given by financial coaches fall under the ethics of possibilities since they are part of informed and creative decisionmaking that draw members closers to good life. OMG provides members with navigational capacity to negotiate the unstable Zimbabwean crisis.

OMG has positioned itself strategically in dealing with precarity and uncertainties that are a result of ill-governance on the part of the state. OMG has strengthened the livelihood activities of its members in times of economic and political crises. Ethnographic insights discussed above show that Pentecostal movements are creative in their approach to deal with challenges that members face in their everyday lives. OMG initiatives are targeted on aspects of life that concern its members. Hart and Sharp (2015, viii) note that meaningful development can be realised when organisations focus their attention on what 'people are already doing' rather than impose their own approaches that often miss the desires of the people. By focusing on what people are concerned with and strengthening people's initiatives, as well as creating strong religious institutions such as housing cooperatives and entrepreneurial incubators, OMG become an effective vehicle for improving the lives of its members. Furthermore, $\mathrm{OMG}$ acts as a conduit that links puny members to corporates such as financial institutions, opening up opportunities that most Zimbabweans lack. Middle-range institutions are often ignored in most development processes, despite their effectiveness in linking broad entities such as state and corporates to ordinary citizens (Powers 2015).

As indicated earlier, OMG is composed of members from different socioeconomic categories, fostering social networks among its members who belong to different social classes. The cross-sectional composition of OMG is a fertile ground for setting up business linkages and mentorship. Furthermore, professionals assist $\mathrm{OMG}$ to come up with pragmatic projects and initiatives for dealing with precarity and uncertainties that continue to threaten the livelihoods and well-being of the majority of Zimbabweans. OMG has gone beyond mere praying, $O M G$ has initiated pragmatic and realistic solutions to the challenges that threaten the livelihoods of its members. OMG is 'promoting 
economic democracy by helping people organize and improve their own lives' (Hart 2015, 4). This is achieved through producing new subjectivities and attitudes that promote shifts in ways things are done.

\section{Notes}

1 In this chapter I anonymise all names of persons and some of religious movements. The study focused on members of $\mathrm{OMG}$ and sought to understand ways in which the OMG shaped members' everyday lives in times of economic and political crisis. While I received consent from the religious movement, the study did not seek official position from the clergy, making it difficult to claim what I present in this chapter as the religious movement's position. Furthermore, a misunderstanding between Ilana van Wyk and Universal Church for the Kingdom of God informed my decision to anonymise the religious movement. (Mafokeng, 2015: https://mg.co.za/article/2015-10-30-letters-to-theeditor-october-30-to-november-5-2015.)

2 Sometimes called First Wave Pentecostalism.

3 This theology is based on the literal reading of Revelation 20 verses 4 to 7 .

4 The pseudonym for founder of $\mathrm{OMG}$ and the main prophet.

5 This statement is derived from the Bible and is the main scripture for 2018.

6 Bond notes were introduced as an export incentive. However, the bond notes have become a form of surrogate currency that is accepted as a legal tender in Zimbabwe only. Bond note is pegged at the same rate with the US\$.

7 Operation Restore Order or Operation Drive out Filth.

8 Literally Operation decent living.

9 The practice of having an extra-marital affair is popularly known as 'Small House Phenomenon'. See Mushinga (2015).

10 Tithe is a tenth and mandatory, free-will offering is a sign of one's faith in God and acknowledgement of that God is the source.

11 An international financial service provider.

12 I have provided the content pages of the booklet to give readers a sense of what is covered in the booklet and some of the planning tools suggested. The attached excerpt is from a book a respondent shared with me.

13 See Sabeta (2017) www.herald.co.zw/co-op-executives-jailed-3-years-for-fraud/. Samukange (2015) www.newsday.co.zw/2015/11/housing-co-op-leaders-accused-ofextortion/.

14 This figure was announced in September 2017 during a cooperatives' meeting in Harare. The financial statement of the cooperative circulated during the meeting also showed the same figures.

15 The decision by OMG members to purchase land is a wise one, another PCC in Zimbabwe obtained land under a government programme. In September 2016 the then president Robert Mugabe publicly attacked the minister of local government for corruptly allocating the PCC land to construct houses for its members. See Ncube (2016) www.newsday.co.zw/2016/09/mugabe-grills-kasukuwere-magaya/. Katunga (2016) www.sundaynews.co.zw/ban-of-housing-co-operatives-welcome/.

16 John 10, 10 (KJV), 'The thief cometh not, but to steal, and to kill, and to destroy: I am come that they might have life, and that they might have it more abundantly'.

17 Precast concrete wall that acts as parameter security in most premises in Zimbabwe. Most Zimbabweans find security in the precast concrete wall. In sermons, I have heard clergy at OMG making reference to durawall, for example during a sermon on 11 June 2018 a pastor made reference to the durawall as its solid protection. For a detailed discussion of this symbolism, see David Maxwell (2006).

18 Clifford Geertz (1973) argues that religion is part of cultural systems. 


\section{References}

Appadurai, Arjun. 2013. The Future as Cultural Fact: Essays on the Global Condition. London \& New York: Verso Books.

Asad, Talal. 1993. Genealogies of Religion; Discipline and Reasons of Power in Christianity and Islam. Baltimore, MD: John Hopkins University Press.

Ashford, Adam. 2005. Witchcraft, Violence and Democracy in South Africa. Chicago \& London: University of Chicago Press.

Berger, Peter. 2008. Under the Radar. Pentecostalism in South Africa and its Potential Social and Economic Role. Johannesburg: CDE in Depth 7. Johannesberg: Centre for Development and Enterprise.

Butler, Judith. 2004. Precarious Life: The Powers of Mourning and Violence. London: Verso Books.

Chirisa, Innocent, Marylin Gaza, and Elmond Bandauko. 2014. 'Housing Cooperatives and the Politics of Local Organization and Representation in Peri-Urban Harare, Zimbabwe.' African Studies Quarterly 15, no. 1: 37-53.

Chitando, Ezra. 2009. 'Deliverance and Sanctified Passports: Prophetic Activities amidst Uncertainity in Harare.' In Dealing with Uncertainty in Contemporary African Lives, edited by L. Haram and C. Bawa Yamba. Stockholm: Nordiska Afrikainstitutet.

Christerson, Brad, and Richard Flory. 2017. The Rise of Network Christianity: How Independent Leaders Are Changing The Religious Landscape. Oxford: Oxford University Press.

Clarke, William Norris. 1994. Explorations in Metaphysics: Being - God - Person. Notre Dame: University of Notre Dame.

Coleman, Simon. 2011. 'Prosperity Unbound? Debating the Sacrificial Economy.' Research in Economic Anthropology 31: 23-45.

Comaroff, Jean, and John Comaroff. 1997. Of Revelation and Revolution: The Dialectics of Modernity on a South African Frontier. Chicago: University of Chicago Press.

Comaroff, Jean, and John Comaroff. 2001. 'Millennial Capitalism: First Thought on a Second Coming.' In Millennial Capitalism and the Culture of Neo-Liberalism, edited by Jean Comaroff and John Comaroff. London: Duke University Press.

Ferguson, James. 1999. Expectations of Modernity: Myths and Meanings of Modernty and Urban Life on the Zambian Copperbelt. Berkeley. University of California Press.

Ferguson, James. 2006. Global Shadows. Africa in the Neoliberal World Order. Durham and London: Duke University Press.

Freeman, Dena. 2015. 'Pentecostalism and Economic Development in Sub-Saharan Africa.' In The Routledge Handbook of Religion and Global Development, edited by Emma Tomalin. Abingdon, Oxon: Routledge.

Geertz, Clifford. 1973. The Interpretation of Cultures. New York: Basic Books Inc.

Gifford, Paul. 1994. 'Some Recent Development in African Christianity.' African Affairs 93: 513-533.

Gifford, Paul. 2002. Christianity and Politics in Doe's Liberia. Vol. 2. Cambridge: Cambridge University Press.

Gifford, Paul. 2004. Ghana's New Christianity: Pentecostalism in a Globalizing African Economy. Bloomington \& Indianapolis: Indiana University Press.

Gifford, Paul. 2009. Christianity, Politics and Public Life in Kenya. London: Hurst \& Company.

Goebel, Allison. 2015. On Their Own: Women, Urbanization and the Right to the City in South Africa. Montreal-Kingstone: McGill-Queen's University Press.

Gono, Gideon. 2008a. First Quarter Monetary Policy Statement: A Focus on Food, Foreign Exchange Generation, Producer Viability and Increased Supply of Basic Commodities. Harare: Reserve Bank of Zimbabwe. 
Gono, Gideon. 2008b. Zimbabwe's Casino Economy: Extraordinary Measures for Extraordinary Challenges. Harare: ZPH Publishers.

Gukurume, Simbarashe. 2017. 'Singing Positivity: Prosperity Gospel in the Musical Discourse of Popular Youth Hip-Hop Gospel in Zimbabwe.' Muziki 12, no. 2: 36-54.

Hart, Keith. 2015. 'Introduction.' In Economy For and Against Democracy, edited by Keith Hart. New York \& Oxford: Berghahn Books.

Hart, Keith, and John Sharp. 2015. 'Introduction.' In People, Money and Power in the Economic Crisis: Perspective from the Global South, edited by Keith Hart, and John Sharp. Berghahn Books.

Haynes, Naomi. 2012. 'Pentecostalism and the Morality of Money: Prosperity, Inequality and Religious Sociality on the Zambian Copperbelt.' Journal of The Royal Anthropology Institute 18: 123-139.

James, Deborah. 2012. 'Money-Go-Round: Personal Economies of Wealth, Aspiration and Indebtedness' Africa: The Journal of the International African Institute 82, no. 1: 20-40.

James, Deborah. 2015. Money from Nothing: Indebtedness and Aspiration in South Africa. California: Stanford University Press.

Jones, Jeremy L. 2010. 'Nothing Is Straight in Zimbabwe': The Rise of the Kukiya-Kiya Economy 2000-2008.' Journal of Southern African Studies 36, no. 2: 285-299. https:// doi.org/10.1080/03057070.2010.485784.

Kanyenze, Godfrey, Prosper Chitambara, and Judith Tyson. 2017. 'The Outlook for the Zimbabwean Economy.' Supporting Economic Transformation, London.

Katunga, Roberta. 2016. 'Ban of Housing Co-Operatives Welcome.' Sunday News, 21 February 2016.

Lessnoff, Michael. 1994. The Spirit of Capitalism and the Protestant Ethic: An Inquiry into the Weber Thesis. Cheltenham MA: Edward Elgar Publishers.

Mafokeng, Nametso. 2015. '“Hostile” Book on Church Is Inaccurate.' Mail EF Guardian, 30 October, 2015.

Majengwa, Jeanette, Ibrahim Kasirye, and Collen Matema. 2012. 'Understanding Poverty in Zimbabwe: A Sample Survey in 16 District.' Economic Development in Africa.

Marshall, Ruth. 2009. Political Spiritualities: The Pentecostal Revolution in Nigeria. Chicago $\&$ London: University of Chicago Press.

Marshall-Fratani, Ruth. 2014. 'Christianity, Anthropology, Politics.' Current Anthropology 55, no. 9.

Maxwell, David. 1998. 'Delivered from the Spirit of Poverty? Pentecostalism, Prosperity and Modernity in Zimbabwe.' Journal of Religion in Africa 28, no. 3: 350-371.

Maxwell, David. 1999. 'Historicizing Christian Independency: The Southern African Pentecostal Movement c. 1908-60.' The Journal of African History 40, no. 2: 243-264.

Maxwell, David. 2006. African Gifts of the Spirit: Pentecostalism and the Rise of Zimbabwean Transnational Religious Movement. Harare: Weaver Press.

Meyer, Birgit. 1998a. 'Commodities and the Power of Prayer: Pentecostalist Attitudes towards Consumption in Contemporary Ghana.' Development and Change 29: 751-776.

Meyer, Birgit. 1998b. "“Make a Complete Break with the Past." Memory and PostColonial Modernity in Ghanaian Pentecostalist Discourse.' Journal of Religion in Africa 28: 316-349.

Meyer, Birgit. 2003. 'Material Mediations and Religious Practices of World-Making.' In Religion Across Media: From Early Antiquity to Late Modernity, edited by Knut Lundby. New York: Peter Lang. 
Meyer, Birgit. 2005. 'Mediating Tradition: Pentecostal Pastors, African Priests, and the Chiefs in Ghananian Popular Films.' In Christianity and Social Change in Africa: Essays in Honor of J.D.Y. Peel, edited by Toyin Falola. Durham: Carolina Academic Press.

Meyer, Birgit. 2007. 'Pentecostalism and Neo-Liberal Capitalism: Faith, Prosperity and Vision in African Pentecostal-Charismatic Churches.' Journal for the Study of Religion 20.

Meyer, Birgit. 2010. 'Pentecostalism and Globalization.' In Studying Global Pentecostalism: Theories and Methods, edited by Allan Anderson, Michael Bergunder, André Droogers, and Cornelis van der Laan. Berkeley: University of California Press.

Millar, Kathleen. 2017. 'Towards A Critical Politics of Precarity.' Sociology Compass 11: 1-11.

Miller, Donald, and Tetsunao Yamamori. 2007. Global Pentecostalism: The New Face of Christian Social Engagement. Berkeley: University of California Press.

Mushinga, Mildred. 2015. 'The 'Small House': An Ethnographical Investigation into Economically Independent Women and Sexual Networks in Zimbabwe.' PhD diss., University of Pretoria.

Ncube, Xolisani. 2016. 'Mugabe Grills Kasukuwere over Magaya.' NewsDay, 8 September 2016.

Paradza, Partson, and Innocent Chirisa. 2017. 'Housing Cooperative Associations in Zimbabwe: A Case Study of Current Housing Consortium in Budiriro, Harare.' JOPPA 4, no. 2: 158-175.

Powers, Theodore. 2015. 'Negotiating State and Market: The South African HIV/AIDS Movement and Social Change.' In Economy For and Against Democracy, edited by Keith Hart. New York: Berghahn.

Robbins, Joel. 2004. 'The Globalization of Pentecostal and Charismatic Christianity.' Annual Review of Anthropology 33: 117-143.

Rotberg, Robert. 2002. 'The New Nature of Nation-State Failure.' Washington Quarterly 25, no. 3: 85-96.

Sabeta, Chipo. 2017. 'Co-Op Executives Jailed 3 Years for Fraud.' Herald, 26 September, 2017.

Samuelsson, Kurt. 1957. A Critique to Max Weber. New York: Harper Torchbooks.

Samukange, Tinotenda. 2015. 'Housing Co-Op Leaders Accused of Extortion.' NewsDay, 10 November, 2015.

Schlemmer, Lawrence. 2008. Dormant Capital: The Pentecostal Movement in South Africa and Its Potential Social and Economic Role. Johannesburg: CDE.

Schwartz, Shalom. 1994. 'Are There Universal Aspects of the Structure and Content of Human Values.' Journal of Social Issues 50: 19-45.

Scott, James C. 1998. Seeing Like a State: How Certain Schemes to Improve the Human Condition Have Failed. New Haven: Yale University Press.

Sorokin, Pitirim A. 1992. The Crisis of Our Time. Oxford: Oneworld Publications.

Stillman, Tyler T., D. Kathleen Voos, Nathanael M. Lambert, and Christa A. Phillips. 2012. 'The Material and Immaterial in Conflict. Spirituality Reduces Conspicuous Consumption.' Journal of Economic Psychology 33: 1-7.

Taru, Josiah, and Federico Settler. 2015. 'Patterns of Consumption and Materialism among Zimbabwean Christians: A Tale of Two Indigenous Churches.' Journal for the Study of Religion 28, no. 2: 113-137.

Tibaijuka, Anna. 2005. 'Report of the Fact-Finding Mission to Zimbabwe to Assess the Scope and Impact of Operation Murambatsvina.' Harare. 


\section{Josiah Taru}

Tsing, Anna Lowenhaupt. 2015. The Mushroom at the End of the World: On the Possibility of Life in Capitalist Ruins. Princeton: Princeton University Press.

United Nations Human Development Report. 2010. United Nations Development Programme. New York: UNDP.

Wacker, Grant. 2001. Heaven Below. Early Pentecostalism and American Culture. Cambridge: Harvard University Press.

Weber, Max. 1930. The Protestant Ethic and the Spirit of Capitalism. London: Allen and Unwin. 